\title{
Teaching And Application In Introductory Finance: Using An Excel-Based Case Study As A Pedagogical Tool
}

Colene L. Coldwell, (Email: colene_coldwell@baylor.edu), Baylor University John T. Rose, (Email: jt_rose@baylor.edu), Baylor University

\begin{abstract}
Recognizing the importance of practical application to a comprehensive business education, teaching, and application are integrated in the finance curriculum by introducing an Excel-based case study in the introductory finance course. The case brings together the theoretical concepts of capital budgeting analysis and the practical business tool of spreadsheet software for students to work in groups to analyze the proposed project and decide whether to accept it.
\end{abstract}

\section{INTRODUCTION}

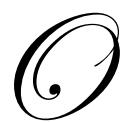

ne of the oft-claimed deficiencies of current business education is that at the end of the day, students are left without a clear notion of how the theories and methodologies they learned in the classroom will be applied in the business world. This issue takes on an added significance for students taking required courses outside their major field; many times they cannot imagine that the course has any relevance to their future careers. Some recent criticisms leveled at today's business schools go further. They claim that without regard for the demands of industry, business faculty and the curriculum devote too much attention to self-prescribed definitions of academic excellence based on the scientific model. The result, it is argued, is an unhealthy preoccupation with theory and quantitative proficiency at the expense of the practical skills that can enable students to become successful business professionals [Bennis and O'Toole, 2005]. On the other hand, the finance discipline is largely quantitative. Thus, any successful integration of theory and practice in financial management necessitates instruction in quantitative methods to merge financial analysis with practical application.

In addition to the concerns and criticisms expressed from within and outside of the academic community, revised accreditation standards for business education have fueled the desire to find and implement tools that will enable business schools to measure student learning. The new accreditation standards, adopted in April 2003 (and revised in January 2004) by the Association to Advance Collegiate Schools of Business (ASCSB), require accredited institutions of higher learning to set appropriate learning goals. In addition, business schools must be able to show that learning has occurred within each degree plan [Thompson, 2004].

Thus, one of the challenges faced by business educators seeking to enhance learning - as well as student and practitioner satisfaction - is to create an environment that provides students the opportunity to apply the concepts and academic skills taught in the classroom to real world situations. Though discussions of actual business scenarios pulled from the business press are certainly useful, there is much additional benefit from moving students beyond the Wall Street Journal to practical application.

In recognition of 1) the importance of real-world applications to a comprehensive business education and 2) current accreditation standards, we recently introduced a capital budgeting case study in our introductory finance course. In so doing, we created a case-situation similar to one that might be encountered by finance professionals to reinforce student learning. 


\section{USING A CAPITAL BUDGETING CASE STUDY TO LINK FINANCE THEORY AND PRACTICE}

Introductory finance texts generally include real-life examples and problems to reinforce students' understanding of finance concepts; see, for example, Keown et al. [2005] and Ross et al. [2004]. Typical end-ofchapter problems give students the opportunity to practice the technical and theoretical concepts covered in the text. These problems often take the form of a simple business situation and encourage students to use financial calculators to find a solution. While anecdotal evidence suggests that this approach provides a valuable method for exposing students to straightforward quantitative financial scenarios, problems tend to focus on a single skill or only one dimension of the material being covered. Some texts include more difficult problems that often require the use of a spreadsheet. Yet such problems typically are still very limited in scope and complexity. Moreover, once these problems are solved, the solutions may be available for students in subsequent semesters to copy (until the next edition of the textbook is released with new problems).

To meet the multiple constraints of requiring end-of-chapter problems, producing business students with both theoretical and practical skills, and meeting accreditation requirements for active learning, we developed a case study in capital budgeting. The choice of a capital budgeting case reflects the fact that capital investment is not taught until the end of the introductory finance course; thus, it incorporates much of the fundamentals of finance. ${ }^{1}$ Further, students must "work" the case using Microsoft Excel, thereby linking finance theory and practice with the use of spreadsheet software to solve a common problem in corporate finance. ${ }^{2}$ The case is rewritten every semester to discourage students from copying previous case solutions.

\section{THE CASE STUDY AS AN EXCEL-BASED GROUP PROJECT}

To complete the case study successfully, students must apply the major finance concepts learned throughout the semester as well as their understanding of Excel. Moreover, students are required to work in groups (the case study solution will not be accepted by any student working alone). The use of groups to augment both student learning and satisfaction and, therefore, to boost the project's value is strongly supported by existing research [Bonwell and Eison, 1991; Davis and Miller, 1996; Robbins, 1994]. After interpreting the information and data presented in the case narrative, each group must complete a pre-designed Excel template that requires them to enter relevant equations and data. The group must then make a decision as to the feasibility of undertaking the proposed project. Their decision is based primarily on the interpretation of the quantitative information derived from their Excel solution; hence, knowledge of the Excel software is a major requirement for success. In addition, students must have a working knowledge of 1) cash flow calculations, 2) popular capital budgeting techniques, most importantly, net present value and internal rate of return, ${ }^{3} 3$ ) the cost of capital and its application in capital budgeting, and 4) decisionmaking and critical-thinking skills.

A sample case and spreadsheet template will illustrate the pedagogy of using Excel to apply finance concepts and methodology in a capital budgeting case scenario. Though fictitious, the case attempts to present a situation similar to one that might be encountered by finance professionals. In addition, it allows the instructor to introduce a number of "what if?" questions, thereby allowing the students to see the sensitivity of their solution to changes in the various case assumptions.

\footnotetext{
${ }^{1}$ The importance of emphasizing capital budgeting is further highlighted by 1992 survey findings of McWilliams and Pantalone [1994], who report that 77 percent of financial executives believe that business school graduates (specifically finance majors) should be required to take a course in capital budgeting.

${ }^{2}$ For a useful guide to using case studies together with lectures to link theory and practice in finance education, see Trahan [1993]. More recently, Bruner, et al. [1999] reviewed the literature of the previous twenty-five years on the relevant issues in incorporating case studies in finance instruction, and Nunnally and Evans [2003] discuss the benefits of using integrative cases in the introductory finance course.

${ }^{3}$ Graham and Harvey [2002] report results from a 1998 survey of a wide variety of firms and industries, indicating that NPV and IRR are the most frequently used methods for evaluating capital investments.
} 
The written case is presented in the next section, followed by several "what if?" questions and the Excel template (Exhibit 1). The case solution is not presented but is available from the authors in Teaching Notes, which include Excel spreadsheet solutions to the case and its associated questions.

\section{“CONCEPT CURLS": A CASE STUDY}

Until a few years ago, Concept Curls, Inc.'s (CCI) most popular line of shampoos and conditioners, Tangled Tresses, led the industry in sales growth. However, over the past three years Tangled Tresses' growth rate has been slipping. Initially, CCI's managers thought the decline in the line's growth simply reflected the recent economic recession in the U.S. economy. Thus, they increased advertising and other promotional activities in an effort to maintain sales until the economy improved. However, as the growth of the Tangled Tresses line has continued to decline while economic data points to an economic upturn, it has become increasingly clear that the source of CCI's problem must be internal.

After an exhaustive analysis of the firm's operations, management believes they have finally identified the primary cause of the drop in Tangled Tresses' sales growth. Marketing research generally suggests that it is the physical appearance of most consumer products - in this case the bottle - that sparks initial consumer interest. The best selling items in this product category are classic colors that imply elegance and sophistication, such as black, white, or silver. Unfortunately, the current Tangled Tresses products are packaged in shades of maroon and burnt orange. As a result, customer surveys report typical customer responses to the Tangled Tresses bottles as "completely dated," "unappealing," and "very unattractive." While management was initially relieved to have identified the problem, their relief has since turned to frustration as changing the bottle color appears to be more difficult than they originally thought.

Actually, the modification is impossible with the existing production equipment. The current bottle manufacturing equipment was purchased three years ago. At that time it was thought to have an economic life of eight years. Still, rapid advancements in technology have eroded the equipment's functionality as well as its financial value. Unfortunately the equipment's design does not allow for any upgrade.

Determined to find a solution, CCI management has zealously researched manufacturing developments. The search reveals a new technology that will enable the production of bottles of various sizes and colors. Replacing the existing inefficient and mechanically obsolete equipment will not only allow for the creation of eye-catching, trendy bottle colors, such as pearlescent pink, but also such classic beauties as black and white.

At first glance the proposed new equipment appears to offer an attractive solution to Tangled Tresses' woes. If implemented, sales revenue in the first twelve months after replacing the equipment are expected to be 10 percent greater than the $\$ 250,500$ monthly level predicted with the existing equipment. Thereafter, sales of the revamped Tangled Tresses line are projected to grow 11 percent in Year 2, 12 percent in Year 3, and then settle at 10 percent annual growth for the remainder of the new equipment's five-year economic life. However, if CCI does not replace the existing equipment, sales growth is expected to continue its steady decline over the remainder of the equipment's economic life, dropping by one percentage point per year from its current (Year 0) growth rate of 5 percent. [Note that the projected Year 1 sales revenue of $\$ 250,500$ with the existing equipment already captures a one-percentage point drop in sales from the current (Year 0) growth rate. Thus, sales growth should decline to 3 percent in Year 2, 2 percent in Year 3, etc.]

In addition to the enhanced sales growth, CCI believes that upgrading the equipment will lead to improvements in operating efficiencies and lower operating costs. Currently (Year 0), the firm earns an operating profit before depreciation expense of 38 percent on the Tangled Tresses line. However, if the new technology is implemented, operating expenses before depreciation are expected to decrease to 53 percent of sales. Additionally, increased production and operating efficiencies will necessitate an immediate increase in working capital requirements. Combined inventories and receivables are estimated to increase by $\$ 67,000$ though this cash outflow will be partially offset by a $\$ 25,000$ increase in accounts payable. In either case-with or without the new equipment - operating expenses before depreciation are expected to increase at the $2.3 \%$ expected annual rate of 
inflation over the next five years (Years 1-5). [Note that the anticipated annual inflationary increase in operating expenses is already included in the 53 percent given for Year 1 if the new equipment is installed.]

Despite the expected benefits of added sales growth and increased operating efficiency, a possible deterrent to the adoption of the new technology is its initial cost. The purchase price of the proposed new equipment is $\$ 1.475$ million, and shipping and installation will likely increase this figure by 15 percent. In addition, at the time of installation the firm expects to train workers to properly operate the new equipment. It is estimated that this training will cost $\$ 15,000$ before tax. Further, the current equipment - purchased just three years ago-is technologically outdated. Therefore, its sale is expected to provide little to offset the initial cost of the proposed new machinery. Indeed, initial inquiries indicate that the machine's only value is as scrap. A potential buyer has offered to buy the machine for 10 percent of its $\$ 975,000$ original installed cost.

If CCI does not invest in the new technology, the firm plans to continue using the existing equipment for the remainder of its economic life. At the end of that time, its estimated salvage value is zero. If the new technology is adopted, the firm plans to use the new equipment for the full five years of its economic life. However, at the end of that period CCI expects technological advancements and enhanced competition from other firms worldwide will limit the equipment's usefulness in the continued production of the Tangled Tresses. Thus, CCI will likely sell the equipment to a competing firm engaged in producing cosmetic and hair salon products for distribution through home cosmetic parties (much like Tupperware parties). CCI estimates that it should be able to sell the equipment at that time for 30 percent of its installed cost. Both the existing and proposed new equipment are classified as seven-year MACRS property and are being depreciated according to their applicable depreciation allowances. [Note: The schedule of MACRS depreciation allowances for seven-year properties is as follows: Year 1-14.29\%; Year 224.49\%; Year 3-17.49\%; Year 4-12.49\%; Year 5-8.93\%; Year 6-8.93\%\%; Year 7-8.93\%; Year 8-4.45\%.]

CCI is in the 40 percent federal-plus-state tax bracket, and it has a 16.5 percent cost of capital (which equals the required rate of return on the project). The firm has unlimited funds to invest and faces no other constraints in its capital budgeting decisions. However, prior to investing in this project, CCI's chief financial officer has asked you to carefully evaluate the proposal to determine its impact on the firm's cash flows, and thus shareholder value. In particular, you should calculate the net present value (NPV) and internal rate of return (IRR) of the proposed project as a basis for your recommendation of whether CCI should proceed to replace the production equipment.

\section{USING THE EXCEL TEMPLATE TO SOLVE THE CASE}

The case should be solved using the Microsoft Excel spreadsheet template printed below (Exhibit 1). Specifically, students should enter an equation (or data if no equation can be specified) from the case scenario into every cell containing an "O" on the Cash Flow Worksheet (through row 46). Second, students should enter the appropriate discount rate in cell B51 along with equations in each of the cells containing an " $\mathbf{X}$ " in rows 52-54 to calculate the project's net present value (NPV). Third, students should compute the project's internal rate of return (IRR) in cell B57 using the trial-and-error method and equations inserted into each of the cells containing a " $Y$ " in rows 58-60. No cell that does not have an "O," "X," or "Y" should be used.

Students should be encouraged to write cell equations as efficiently as possible. This will ensure that they obtain accurate results when they modify the spreadsheet to answer the "what if?" questions. Additionally, they should note that several items on the spreadsheet template are listed twice with a "1" or " 2 " after the item, e.g., R1 and R2. The "1" refers to the value of that item without the project; the " 2 " refers to the value of that item with the project. Finally, depreciation equations should apply the depreciation schedule in row 16 to the installed cost (depreciable basis) of the old asset and the depreciation schedule in row 17 to the installed cost of the new asset.

\section{"WHAT IF?" QUESTIONS}

In many cases capital budgeting requires a "leap of faith" owing to the fact that much of the analysis is based on projected figures that may turn out to be greatly over- or under-estimated. And miscalculations can lead to costly mistakes. Thus, it is important to analyze assumptions carefully and to check (and recheck) projections to see how 
variations in projected figures may affect calculation and ultimately the decision. With that in mind and to see the sensitivity of the case solution to the various projections, students may be presented a series of "what if?" questions to explore how the solution might vary with different assumptions. Examples of such questions for this case are as follows:

- Would the case solution change if operating expenses for the revamped line were expected to decline to only 57\% of sales? Explain, making reference to both NPV and IRR and using specific figures. What does the analysis say about the sensitivity of NPV and IRR to CCI's expense projections?

- $\quad$ Tax laws are typically revised every few years. With that in mind, would the case solution change if the tax law were amended to eliminate accelerated depreciation, thus requiring that the new production equipment (but not the old equipment) be depreciated over its 5-year economic life using the straight-line method? Explain, making reference to both NPV and IRR and using specific figures. Is there anything unusual about the calculated NPV and IRR answer, i.e., an answer different from what one might have expected? If so, explain what happened. [Note: $\mathrm{n}$ using straight-line depreciation for tax purposes, do not subtract the estimated salvage value from the cost of the project to calculate the depreciable basis.]

- $\quad$ Projecting salvage value is particularly difficult. Along that line, suppose CCI did not expect any salvage value from the proposed new equipment at the end of its economic life. In that case, would the case solution change? Explain, making reference to both NPV and IRR and using specific figures. What does the analysis say about the sensitivity of NPV and IRR to the projected salvage value?

- $\quad$ Refer again to the previous question. With no expected salvage value from the propose new equipment, what is the most that CCI could pay for the equipment (purchase price plus shipping and installation) in order for the project to still be in the best interests of shareholders? Explain, making reference to both NPV and IRR and using specific figures.

- Suppose CCI projects an increase in inflation, leading to an increase in the cost of capital for the project to 18.0 percent. Would the case solution change? Explain, making reference to both NPV and IRR and using specific figures. What does the analysis say about the sensitivity of NPV and IRR to the project's cost of capital?

- $\quad$ Assume all of the new assumptions from the questions above. Would the net effect of these changes affect the case solution? Explain, making reference to both NPV and IRR and using specific figures

\section{REFERENCES}

1. Bennis, Warren G. and James O'Toole, 2005. How Business Schools Lost Their Way, Harvard Business Review, 83:5 (May), 96-104.

2. Bonwell, C. and J. Eison, 1991. Active Learning: Creating Excitement in the Classroom, ERIC Digest. ERIC Clearinghouse on Higher Education, Washington, D.C.

3. Bruner, Robert F., Benton E. Gup, Bennie H. Nunnally, Jr., and Laurence C. Pettit, 1999. Teaching with Cases to Graduate and Undergraduate Students, Financial Practice and Education, 9:2, 138-146.

4. Davis, Barbara D. and Thomas R. Miller, 1996. Job Preparation of the $21^{\text {st }}$ Century: A Group Project, Journal of Education for Business, 72:2 (November, December), 69-74.

5. Graham, John and Campbell Harvey, 2002. How Do CFOs Make Capital Budgeting and Capital Structure Decisions? Journal of Applied Corporate Finance, 15:1 (Spring), 8-23

6. Keown, Arthur J., John D. Martin, J. William Petty, and David F. Scott, Jr., 2005. Foundations of Finance, $4^{\text {th }}$ ed. Upper Saddle Back, NJ: Prentice Hall.

7. McWilliams, Victoria B. and Coleen C. Pantalone, 1994. Structuring the Finance Curriculum: A Survey, Financial Practice and Education, 4:1 (Spring/Summer), 37-46.

8. Robbins, Tina, 1994. Meaningfulness and Community in the Classroom: The Role of Teamwork in Business Education, Journal of Education for Business, 69:6 (July/August), 312-317.

9. Ross, Stephen A., Randolph W. Westerfield, and Bradford D. Jordan, 2004. Essentials of Corporate Finance, $4^{\text {th }}$ ed. New York, NY: McGraw-Hill.

10. Thompson, Kenneth R., 2004. A Conversation with Milton Blood: The New AACSB Standards, Academy of Management Learning \& Education, 3: 4 (December), 429-439.

11. Trahan, Emery A., 1993. Bridging the Theory-Practice Gap: An Integrated Case-Study Approach, Financial Practice and Education, 3:2 (Fall), 19-22. 
